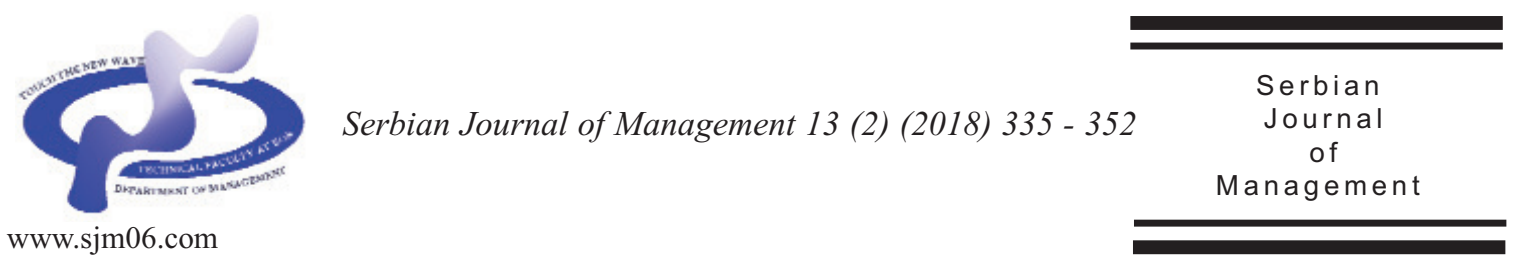

\title{
DETERMINING FACTORS INFLUENCING CLOUD SERVICES ADOPTION IN INDIA
}

\author{
Garima Rastogi*, Hemraj Verma and Rama Sushil \\ Dehradun Institute of Technology - DIT University, \\ Dehradun, Uttarakhand 248009, India
}

(Received 16 February 2017; accepted 5 September 2017)

\begin{abstract}
This study identifies the factors influencing cloud services adoption in India using Unified Theory of Acceptance and Use of Technology (UTAUT) model. Role of perceived risk as a moderator in adoption of cloud services, too, has been examined along with other moderators such as gender, age, experience and voluntariness of use as stated in UTAUT model. Following a descriptive research design, a survey was conducted and a structured questionnaire was administered randomly to a sample of 379 respondents in Dehradun region. Most of the relationships confirmed to UTAUT model. Performance expectancy and effort expectancy emerged as the two most significant factors influencing cloud services adoption. Perceived risk, too, played a significant moderating role in adoption of cloud services. Cloud based services are relatively new to consumers in India. The benefits of these cloud technology can only be reaped fully if more and more customers adopt it. Also, various types of risks, such as financial loss, data loss, privacy etc., are associated with using cloud services. Therefore, this study may have immediate implications for cloud service providers.
\end{abstract}

Keywords:adoption, moderator, influencing, services, determining factor

\section{INTRODUCTION}

Cloud computing is a relatively new technological innovation that has made it possible to replace traditional physical resources with low cost virtual service platforms. Cloud computing services include Information as a service (IaaS), Platform as a Service (PaaS) and Software as a Service
(SaaS) (Chonka et al., 2011). By availing these services, a user can easily access remote distance servers over internet requiring minimal interaction with service providers (Marston et al., 2011). In other words, consumers are given on-demand access from a given device and location (Stein et al., 2013).These services are quite useful to customer as data accessibility is

\footnotetext{
* Corresponding author: garimaverma.research@gmail.com
}

DOI: $10.5937 /$ sjm13-13207 
reliable and flexible (Gray, 2013). Further, cloud computing services empower users in handling the data easily. Be it storing data, working on it individually or on shared manner or retrieving it when needed, cloud computing services enable consumers to pool the information and work on it as well. For this reason, cloud computing is also known as service or network computing (Chonka et al., 2011). Also, consumers have gained access to all these functionalities of existing information technology services in a mobile technology format now (Marston et al. 2011). Cloud computing services save consumers money by handling information maintenance needs and by providing quick technology applications without the high upfront costs of buying hardware or software resources (Karakas \& Manisaligil, 2012). More consumers are using cloud computing services, as it provides a dynamic platform for information services that are constantly being updated (Karakas \& Manisaligil, 2012). Cloud computing for consumers provides the benefit of better storage and capacity utilization made possible by technological innovation (Karakas \& Manisaligil, 2012). It also encourages technological innovation through comprehensive computing platform that can be used by consumers for multiple usages (Vouk, 2008). Despite all benefits, the rate of cloud computing services adoption is very slow. There may be several reasons for this and one of which could be the fact that Indian consumers are new to services. This establishes a need for a comprehensive research so that the true benefits of these services may be reaped fully. The current study is an attempt in this direction and examines the factors influencing cloud services adoption in India.

\section{LITERATURE REVIEW}

For successful implementation of any technology, it is highly desirable that potential users first accept it. Users generally associate risks with anything new and therefore would prefer to weigh the impact it may have on their work performance or life. Most of the technology implementations in past have failed primarily because they had low level of acceptance amongst users. Researchers have realized this need and therefore have proposed various theories and models that have originated from the fields of information system, sociology and psychology. These models have been developed to understand the factors that impact behavioral intentions to use technology. Some of the popular theories and models are the Theory of Reasoned Action (TRA) (Fishbein \& Ajzen, 1975); the Theory of Planned Behavior (TPB) (Ajzen, 1991), the Technology Acceptance Model (TAM) (Davis et al., 1989); the Combined-TAMTPB model (C-TAM-TPB) (Taylor \& Todd, 1995), the Motivational Model (MM) (Davis et al., 1992), the Innovation Diffusion Theory (IDT) (Rogers, 1995) and the Unified theory of Acceptance and Use of Technology (UTAUT) (Venkatesh et al., 2003). To understand behavioral intention of adopting a technology, researchers in the past have applied these models in variety of ways - using a model individually, combining two or more models and/or adapting an individual or combined model. However, most of these models explain only thirty to thirty six percent of behavioral intentions (Venkatesh et al., 2003). In 2003, Venkatesh et al. developed UTAUT model (shown in Fig. 1) by combining eight of these models such as TAM, theory of reasoned action (TRA); motivational model (MM); theory of 
planned behavior (TPB); combined TAM and TPB (C-TAM-TPB); model of PC utilization (MPCU); diffusion of innovation theory (DOI); and social cognitive theory (SCT).

It may be important to discuss important perspectives available on technology acceptance here. One of the earliest perspective on acceptance of technology has been innovation diffusion theory (Rogers, 1995). Although, it does not deal specifically with technology but yet this theory offers a conceptual framework to understand how an innovation gets acceptance by categorizing the takers of an innovation into five categories -innovators, early adopters, early majority, late majority, and laggards. The categorization was done on the basis of how fast a user adopts a technological innovation. As per this theory, there are five characteristics of innovations that determine how fast it is diffused. These five characteristics are relative advantage (the extent to which a technology is better than over current tools), compatibility (its conformance to social practices and norms among users), complexity (ease of use or learning), trialability (the opportunity to experience before committing to use it), and observability (the extent to which the technology's gains are clearly visible). Despite simplicity of the framework, the theory fails to explicitly deal with user acceptance of technology. For example, it does not explain how user acceptance takes place and which factors are relatively more important for technology acceptance. This is an area where TAM models score more as organizations are able to pay more attention to important factors while implementing technology adoption.

Further, Bagozzi (2007) proposed a new paradigm to understand technology adoption decision. Bagozzi (2007) and $\mathrm{Wu}$ (2009) criticized TAM models for being too simple and insufficient to cover all elements of a phenomenon under investigation. Especially, Bagozzi (2007) questioned theoretical linkage between intention and actual use for a system as the time lag between intention to use and actual adoption is full of uncertainties which might moderate an individual's decision to use a technology. $\mathrm{He}$ also pointed out that merely using a technology cannot be a terminal goal but rather only a means to achieve more fundamental goals such as storing, retrieving and using data for effective decision making. He argued that it is important to consider technology adoption as a process having various stages such as goal desire $\rightarrow$ goal intention $\rightarrow$ action desire $\rightarrow$ action intention. Unlike TAM models, intention formation here was followed by planning dealing with when, where and how of using technology, overcoming difficulties, goal achievement, realigning efforts and evaluating progress and even changing goals and mean. He posited that these processes complete the linkage between intention and actual behavior and also between behavior and goal realization.

Given the limitation of TAM and related models, this proposed paradigm appears to be quite promising. However for some reasons this paradigm has not been able to gain popularity. One of the possible reasons could be complexity in its implementation. Since most organizations would require objective answers to design a system for technology adoption, this paradigm fails to provide the same and seems to be more abstract. For example, a firm would like to know in certain terms that which factors affect users' adoption of a new technology. TAM and related models, despite their 
limitations, provide objective answers to this question whereas the paradigm proposed by Bagozzi fails to do so as there may be large number of unseen factors that may be involved in the process. This would make a decision makers life a lot more difficult than to refer something that is more easy and tangible. Also, human mind mostly cannot process all available information and generally prefer to process limited information for taking decisions that are just satisficing and not necessary the best. So it is quite likely that most managers would resort to a simpler model than working hard to identify large number of factors specific to a technology. Further, technology users in organizations are generally bound by larger organizational goals than the individuals' goals wherein individuals might be asked to adopt a technology irrespective of their liking or disliking for a technology. So the question of linkage between terminal goal and more fundamental goal, too, may not fit always so well. Even in cases where individual fundamental goals are aligned with larger organizational goals, TAM and related models do capture that through factor such as perceived utility (in TAM Models) or performance expectancy (in UTAUT model). This factor captures the usefulness of a technology to a user from the utility standpoint quite adequately. In other words, a user would adopt a technology more readily if it enables him or her to achieve his individual goals, as determined larger organizational goals, more easily.

\subsection{Unified Theory of Acceptance and Use of Technology (UTAUT) Model}

This model had six core constructs namely performance expectancy, effort expectancy, social influence, facilitating conditions, behavioral intention, and use behavior and four moderating variables gender, age, experience and voluntariness. UTAUT was described as a newer theoretical model and said to have overcome limitations of previous models (Marchewka et al., 2007; Min et al., 2008; Chang et al., 2015). This model was able to explain seventy percent of the variation in user's behavioral intention and thus was deemed far more superior to its predecessors (Cao et al., 2013; Alharbi, 2014). Despite having greater explanatory power, limited studies have used this model in cloud computing studies (San-Martín \& Herrero, 2012; Cao et al., 2013). In the past, researchers have largely used TAM or DOI model to understanding cloud technology adoption (Langkau et al., 2012; Gupta et al., 2013; Burda \& Teuteberg, 2014; Udo et al., 2016).

Using UTAUT model, a study by Cao et al. (2013) adapted it to include three more constructs viz. risk, cost, and innovativeness to existing six constructs namely: performance expectancy, effort expectancy, social influence, facilitating condition, and adoption intention and use behavior. The study found that all the variables significantly influenced adoption of cloud services. Another study by Lian (2015), too, used an adapted model of original UTAUT model to include trust, perceived risk, and security constructs. The study found four factors viz. effort expectation, social influence, trust and perceived risk, having significant effects on the behavioral intention to adopt cloud computing in e-governance services.

\subsection{Perceived Risk}

In a study by Bauer (1960), Perceived Risk (PR) has been defined as a combination 


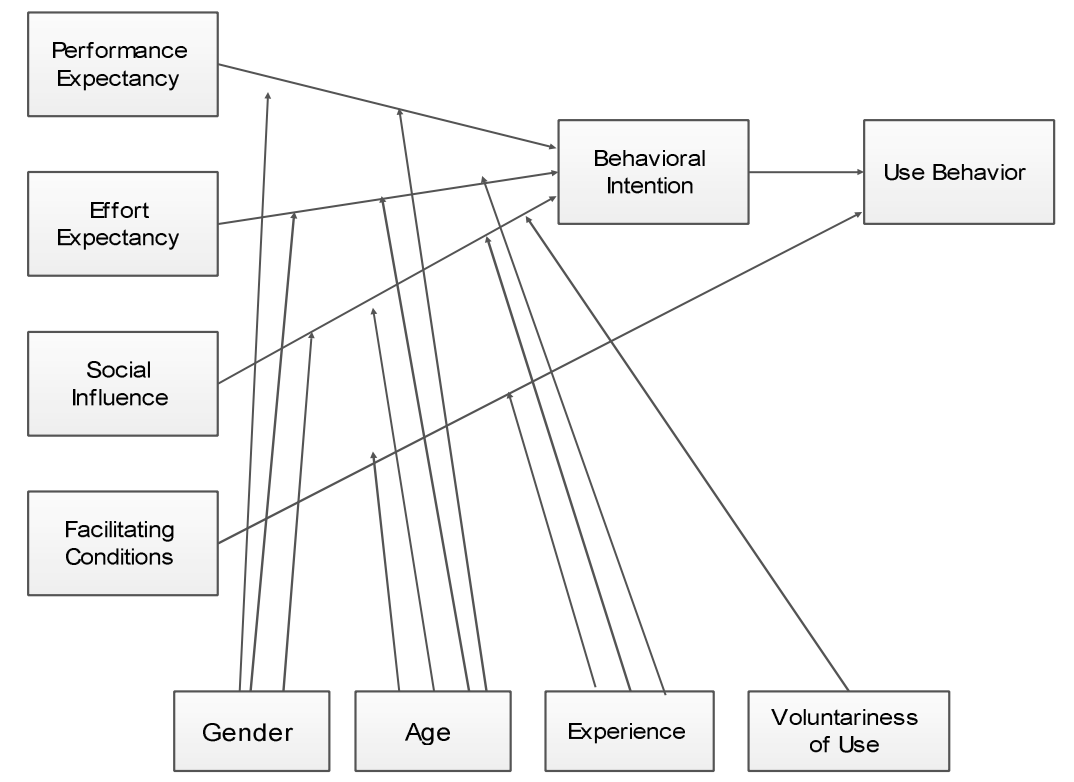

Figure 1. Unified Theory of Acceptance and Use of Technology model (Venkatesh et al., 2003)

of uncertainty and seriousness of outcome involved. Most of the information system adoption decisions generate a feeling of uncertainty, discomfort and or anxiety (Dowling \& Staelin, 1994), conflict in consumer (Bettman, 1973), psychological discomfort (Zaltman \& Wallendorf, 1983) making consumer feel uncertain (Engel et al., 1986), resulting into cognitive dissonance (Festinger, 1957; Germunden, 1985) and pain due to anxiety (Taylor, 1974). Cognitive dissonance takes place post purchase evaluation of a product's benefits, costs, utility and risks. For cloud services adoption context, utility gains may be in the form of lessor costs, more efficiency etc. and risks may be related to performance of service, loss of information, privacy of data etc. Therefore, it may be plausible to assume that higher PR will reduce the influence of perceived utility and social influence required on intention to use a technology. Also, higher PR may also increase the impact of perceived effort required on intention to adopt a technology. Further, it is may also be inferred that perceived risk effect will be captured in facilitating conditions therefore it shall have no impact.

\section{PROPOSED RESEARCH MODEL AND HYPOTHESIS FORMULATION}

The proposed model is an adaptation of original UTAUT model and posits perceived risk to be one of the significant moderator.

The first construct, Performance expectancy, in UTAUT model is similar to the construct Perceived Usefulness, used in TAM, Presented in Figure 1 (Venkatesh et al., 2003; Min et al., 2008). It has been found as one of the most important factor that influenced user adoption of technology directly and positively. (Venkatesh et al., 2003; Wu, 2011; Cao et al., 2013; Shin, 2013; Park \& Ryoo, 2013; Park \& Kim 2014). In this study too, it is posited that perceived benefits of cloud computing might increase the intention to adopt it. Therefore, it can be hypothesized that: 
H1: Performance expectancy has a positive effect on users' behavioral intention to use cloud computing services.

Further, as conceptualized in UTAUT (Venkatesh et al., 2003), Gender and Age will moderate the above relationship significantly and therefore it is hypothesized that:

H1a: Performance expectancy has a stronger positive effect on users' behavioral intention to use cloud computing services in case of men.

H1b: Performance expectancy has a stronger positive effect on users' behavioral intention to use cloud computing services in case of younger users.

Also from literature discussion on perceived risk, following hypothesis may be posited:

H1c: Higher perceived risk will negatively moderate the relationship between Performance expectancy and users' behavioral intention to use cloud computing services.

The second construct in UTAUT model is Effort expectancy and it is similar to perceived ease of use in TAM (Venkatesh et al., 2003; Min et al., 2008). Several research studies (Wu, 2011; Gupta et al., 2013; Burda \& Teuteberg, 2014; Lian 2015) have found that there is strong influence of perceived ease of use on the behavioral intention to adopt cloud computing services. Thus, it is posited that:

H2: Effort expectancy has a positive effect on users' behavioral intention to use cloud computing services.
Also, it is hypothesized that:

H2a: Effort Expectancy has a stronger effect on users' behavioral intention to use cloud computing services in case of female users.

H2b: Effort Expectancy has a stronger effect on users' behavioral intention to use cloud computing services in case of older users.

H2c: Effort Expectancy has a stronger effect on users' behavioral intention to use cloud computing services in case of users with lesser experience.

H2d: Higher perceived risk will negatively moderate the relationship between Effort Expectancy and users' behavioral intention to use cloud computing services.

Social Influence refers to influence of peers, co-workers or important referent groups on one's behavioral choice. This construct is similar to the construct subjective norm used in TRA (Ajzen \& Fishbein, 1980) and the TPB (Ajzen, 1991). A study by Park and Ryoo (2013) found subjective norm as one of the important antecedent to behavioral intention. Also, social influence too have been found to be an important factor in IT adoption (Venkatesh et al., 2003; Cao et al., 2013). Therefore, it may be posited that:

H3: Social influence has a positive effect on users' behavioral intention to use cloud computing services.

H3a: Social Influence has a stronger effect on users' behavioral intention to use 
cloud computing services in case of female users.

H3b: Social Influence has a stronger effect on users' behavioral intention to use cloud computing services in case of older users.

H3c: Social Influence has a stronger effect on users' behavioral intention to use cloud computing services when voluntariness to use not present.

H3d: Social Influence has a stronger effect on users' behavioral intention to use cloud computing services in case of users with lesser experience.

H3e: Higher perceived risk will negatively moderate the relationship between Social influence and users' behavioral intention to use cloud computing services.

Facilitating conditions included organizational factors such as availability of technical and organizational requirements in the form of internet bandwidth and reliability of the infrastructure. These conditions have been found to affect the user adoption of the cloud (Stieninger \& Nedbal, 2014). Venkatesh et al. (2003) also found a direct link between facilitating condition and use behavior. A study by Cao et al. (2013), too, founded that the final use adoption of the cloud computing was affected by facilitating condition. Based on the above, it may be hypothesized that:

H4: Facilitating condition has a positive effect on use behavior of cloud computing services.

H4a: Facilitating conditions have a stronger effect on use behavior of cloud computing services in case of older users.

H4b: With higher experience, facilitating conditions have a stronger effect on use behavior of cloud computing services adoption.

UTAUT model (Venkatesh et al., 2003) found that behavioral intention has a significant, direct and positive impact on actual use of technology. Confirming the same, Optiz et al. (2012) and Taylor and Hunsinger (2011) too found that behavioral intention had a significant influence on actual use of cloud computing services. This study, too, posits that behavioral intention will have a significant impact on use behavior of cloud computing. Therefore, it is hypothesized that:

H5. Behavioral intention has a positive effect on use behavior of cloud computing service.

Final conceptual model based on presented hypothesis is presented in Figure 2.

\section{METHODOLOGY}

This study was descriptive in nature wherein a survey was conducted using a structured questionnaire. A sample of 379 respondents was selected randomly from Dehradun city. The sample included variety of respondents such as businessmen, housewives, faculty members, students of management and engineering institutions, professionals working in IT industry and other private organizations. They were administered the questionnaire over a period 


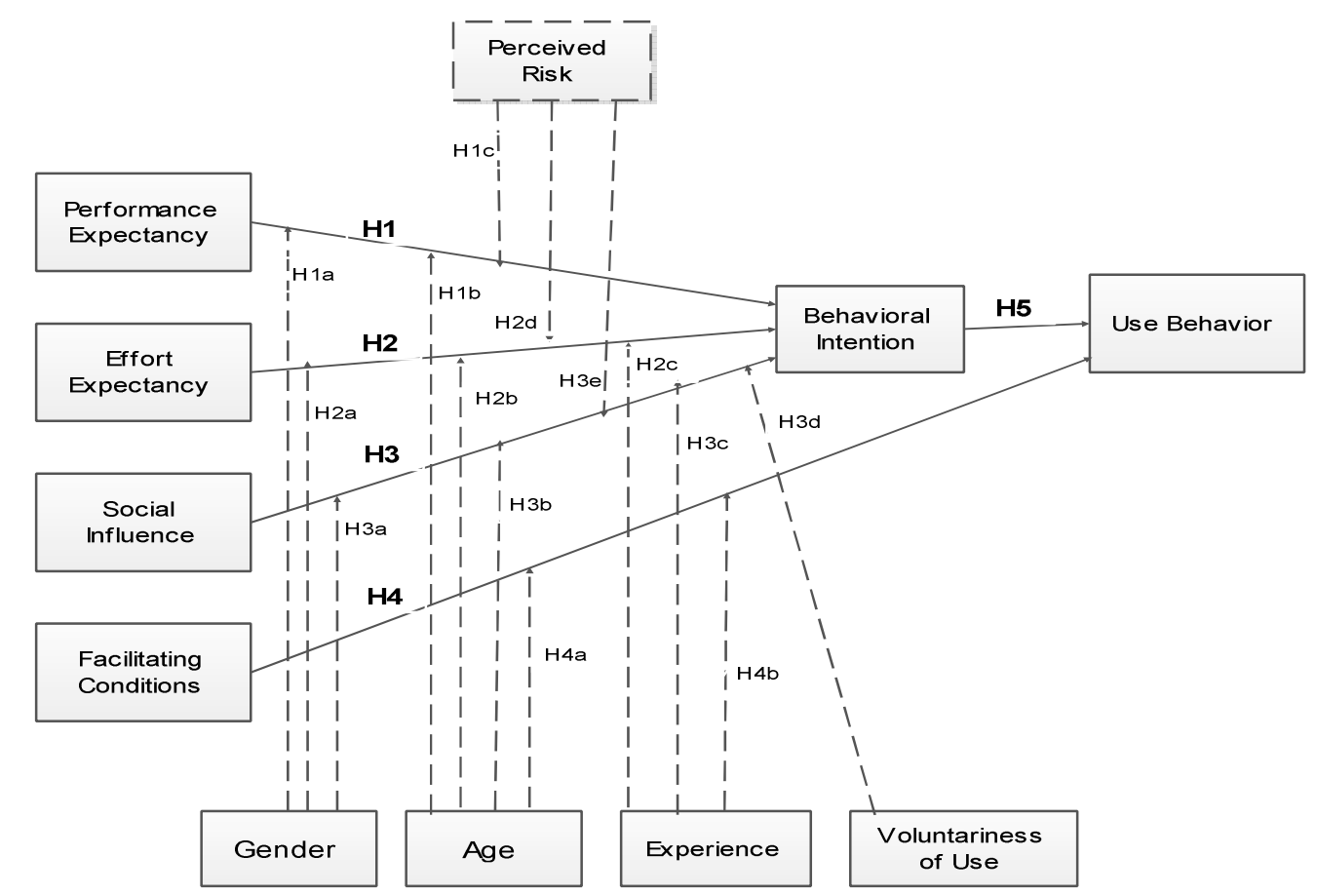

Figure 2. Proposed Model (Adapted from UTAUT model)

of over three months from Sept.2016 to Nov.2016. In total, 308 questionnaires were found complete and therefore were used for final data analysis.

A five point Likert scale based instrument was used in this study for data collection. It was largely adapted from scale developed by Venkatesh et al. (2003). However, for selecting appropriate items for capturing cloud technology adoption related responses, eight IT professional working in three companies and involved actively in cloud technology implementations were approached for in-depth interviews. Further, a pilot study was carried out on a small sample of 45 students studying in an engineering college to refine the instrument and ensure its reliability and validity. The instrument had three sections; first section was about general questions related to usage of cloud technology, second section carried statements related to six key constructs (performance expectancy, effort expectancy, social influence, facilitating conditions, behavioral intentions and Use behavior) carrying four items each as given in UTAUT model by Venkatesh et al. (2003). The last section had questions related to respondents' demographic characteristics such as gender, age, voluntariness of use, and experience. All these have been established as significant moderators in the original UTAUT model. Statements were also included in the questionnaire to capture responses for an additional moderator i.e. Perceived risk. The data was analyzed with the help of SPSS 22.0 and the proposed relationships were tested using structural equation modeling on AMOS 18. 


\section{RESULTS AND DISCUSSION}

\subsection{Results of Measurement model}

To validate the scale validity, a confirmatory factor analysis (CFA) with AMOS was performed. The measurement model was tested using a number of fit indices, including relative Chi-square minimum/ degrees of freedom, goodness of fit index (GFI), Adjusted goodness of fit (AGFI), normed fit index (NFI), comparative fit index (CFI), and Root Mean Square of Approximation (RMSEA) (Hair et al., 2010).

\subsubsection{Scale Reliability and convergent validity}

Internal consistency of the instrument was tested by calculating two popular measures of reliability viz. Chronbach Alpha and Composite reliability for each of the constructs used in the model (Table 1). It was found that both of these measures of internal consistency were more than the suggested level of 0.70 (Nunnally, 1978; Hair et al., 2010) as exhibited in Table 1. Composite Reliability (CR) too is established as it is found to be greater than 0.50. Also, it is greater than Average variance extracted and average shared variance. Moreover, principle component analysis suggested a very high inter-item correlations within each of six constructs used in the study, indicating sufficient convergent validity as well.

\subsubsection{Discriminant Validity}

For establishing discriminant validity, the average variance extracted by a construct should be greater than the variance it shares with other constructs (Hair et al., 2010). In table 2, the diagonal elements represent the square root of average variance extracted and all other off-diagonal elements are

Table 1. Psychometric properties of constructs

\begin{tabular}{|c|c|c|c|c|c|}
\hline Construct & $\begin{array}{l}\text { Factor } \\
\text { Loadings }\end{array}$ & $\begin{array}{c}\text { Cronbach } \\
\alpha\end{array}$ & CR & AVE & ASV \\
\hline \multirow{4}{*}{ Performance Expectancy } & 0.970 & \multirow{4}{*}{0.867} & \multirow{4}{*}{0.919} & \multirow{4}{*}{0.740} & \multirow{4}{*}{0.149} \\
\hline & 0.850 & & & & \\
\hline & 0.820 & & & & \\
\hline & 0.790 & & & & \\
\hline \multirow{4}{*}{ Effort Expectancy } & 0.720 & \multirow{4}{*}{0.815} & \multirow{4}{*}{0.863} & \multirow{4}{*}{0.612} & \multirow{4}{*}{0.198} \\
\hline & 0.880 & & & & \\
\hline & 0.790 & & & & \\
\hline & 0.730 & & & & \\
\hline \multirow{4}{*}{ Social Influence } & 0.870 & \multirow{4}{*}{0.881} & \multirow{4}{*}{0.930} & \multirow{4}{*}{0.768} & \multirow{4}{*}{0.144} \\
\hline & 0.810 & & & & \\
\hline & 0.880 & & & & \\
\hline & 0.940 & & & & \\
\hline \multirow{4}{*}{ Facilitating Conditions } & 0.920 & \multirow{4}{*}{0.801} & \multirow{4}{*}{0.841} & \multirow{4}{*}{0.573} & \multirow{4}{*}{0.115} \\
\hline & 0.690 & & & & \\
\hline & 0.650 & & & & \\
\hline & 0.740 & & & & \\
\hline \multirow{3}{*}{ Behavioral Intention } & 0.780 & \multirow{3}{*}{0.743} & \multirow{3}{*}{0.782} & \multirow{3}{*}{0.550} & \multirow{3}{*}{0.189} \\
\hline & 0.840 & & & & \\
\hline & 0.580 & & & & \\
\hline \multirow{3}{*}{ Use Behavior } & 0.810 & \multirow{3}{*}{0.823} & \multirow{3}{*}{0.881} & \multirow{3}{*}{0.712} & \multirow{3}{*}{0.188} \\
\hline & 0.870 & & & & \\
\hline & 0.850 & & & & \\
\hline
\end{tabular}


Table 2. Convergent and discriminant validity of the scale

\begin{tabular}{ccccccc}
\hline & PE & EE & SI & FC & BI & UB \\
\hline PE & $\mathbf{0 . 7 4 0}$ & & & & & \\
EE & 0.421 & $\mathbf{0 . 6 1 2}$ & & & & \\
SI & 0.325 & 0.512 & $\mathbf{0 . 7 6 8}$ & & & \\
FC & 0.339 & 0.310 & 0.213 & $\mathbf{0 . 5 7 3}$ & & \\
BI & 0.501 & 0.442 & 0.330 & 0.403 & $\mathbf{0 . 5 5 0}$ & \\
UB & 0.313 & 0.511 & 0.445 & 0.398 & 0.477 & $\mathbf{0 . 7 1 2}$ \\
\hline
\end{tabular}

Note: PE- Performance Expectancy, EE- Effort Expectancy, SI- Social Influence, Facilitating Conditions, BI- Behavioral Intention, and UB - Use Behaviour

Table 3. Structural equation model fit Summary

\begin{tabular}{lccccr}
\hline Model & NPAR & CMIN & DF & P & CMIN/DF \\
\hline Default model & 85 & 611.23 & 303 & 0.000 & 2.017 \\
Saturated model & 444 & 0.000 & 0 & & \\
Independence model & 25 & 1742.786 & 404 & 0.000 & 4.338
\end{tabular}

CMIN/DF should be less than 3, which is 1.746 in this model.

\begin{tabular}{lcclll} 
Model & CFI & GFI & $\begin{array}{l}\text { NFI } \\
\text { Delta1 }\end{array}$ & $\begin{array}{l}\text { TLI } \\
\text { rho2 }\end{array}$ & RMSEA \\
Default model & 0.911 & 0.922 & 0.945 & 0.955 & 0.051 \\
\hline
\end{tabular}

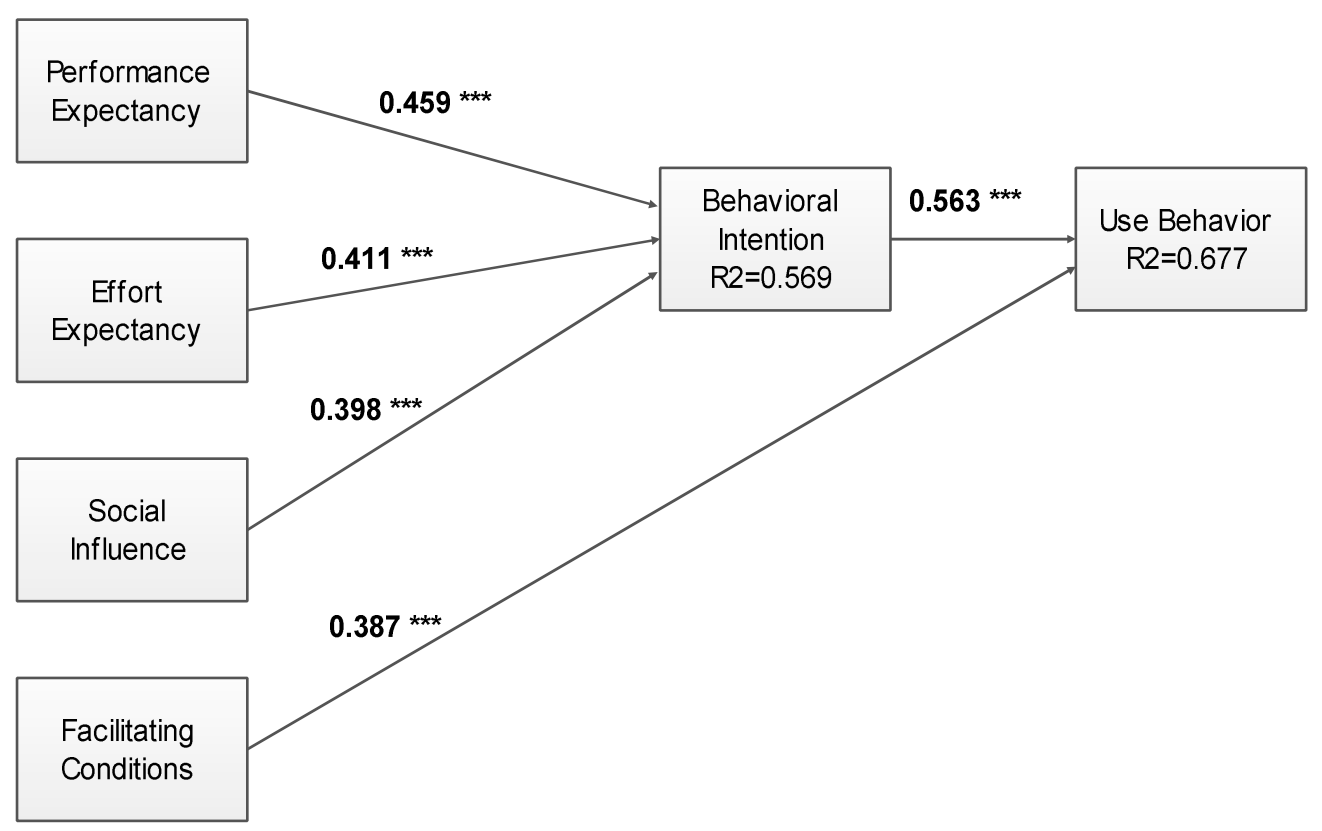

Figure 3. Results of structural model 
correlations among constructs (Shared Variance). Since all off-diagonal values (Table2) are less than diagonal values indicating that average variance extracted for each construct is more than their shared variance with other constructs. This provides evidence that the scale used for the research has sufficient discriminant validity.

\subsection{Results of Structural Equation Model Testing}

To finally test the model, structural equation modeling was applied and the model indicated a good fit. Most of the measures were found to consistent with the standard acceptable values as shown in Table 3.

Overall fit measures were found to be satisfactory (Table 3 ). The first measure, chi square minimum/Degrees of freedom (CMIN/d.f.) was found to be 2.017. This was less than the standard acceptable value of 3 . Other indices such as Comparative Fit Index (CFI), Goodness of Fit Index (GFI), Normed Fit Index (NFI) and Tucker-Lewis index (TLI) were $0.911,0.922,0.945$ and 0.955 respectively. All these values were greater than the minimum acceptable value of 0.900 indicating good model fit (Hair et al., 2010). Also, the value of root mean square error of approximation (RMSEA) was 0.063 which was less than the standard acceptable value of .05. All these measures strongly supported the overall fitness of UTAUT model for cloud technology adoption.

As shown in the Fig. 3, all hypothesis predicting direct relationships were found significant at $p=.01$ and were supported by the model. The results are also shown in Table 4. Performance expectancy was found to be one of the most significant factor in affecting behavioral intention (BI) for use of cloud technologies with highest $b=0.459$, $p<0.01$. Next important factor was effort expectancy (BI) with $b=0.411, p<0.01$ followed by social influence (SI) with $b=0.398, p<0.01$ and facilitating conditions (FC) with $b=0.387, p<0.01$. Also, behavioral Intention (BI) was found to be a significant predictor of Use behavior (UB) with $b=0.563, p<0.01$.

\subsection{Moderation results}

The moderation analysis was done using AMOS 18.0 by fitting structural equation models using proposed model on two categories of each of the moderators-Gender (Male and Female), Age Group (Old and Young), Experience (Little of No experience and More Experience), Voluntariness of Use (Voluntary and Non-Voluntary) and perceived risk (low perceived risk and high perceived risk). For both the categories of all moderators, the structural models were

Table 4. Results of hypothesis testing

\begin{tabular}{lrrrrr}
\hline Hypothesis & \multicolumn{1}{l}{$\begin{array}{l}\text { Path } \\
\text { estimates }\end{array}$} & S.E. & \multicolumn{1}{c}{ t-statistics } & P-value & \multicolumn{2}{c}{$\begin{array}{l}\text { Supported or } \\
\text { not }\end{array}$} \\
\hline BI $<---~ P E$ & 0.459 & 0.049 & 8.231 & $0.001 * * *$ & Yes \\
BI <--- EE & 0.411 & 0.355 & 7.877 & $0.000^{* * *}$ & Yes \\
BI <--- SI & 0.398 & 0.401 & 9.352 & $0.003 * * *$ & Yes \\
UB <--- FC & 0.387 & 0.339 & 8.332 & $0.002^{* * *}$ & Yes \\
UB <--- BI & 0.563 & 0.377 & 11.112 & $0.000^{* * *}$ & Yes \\
\hline
\end{tabular}

Notes: *** Significance at p_0.001; PE- Performance Expectancy, EE- Effort Expectancy, SI- Social Influence, Facilitating Conditions, BI- Behavioral Intention, and UB - Use Behavior 
Table 5. Gender as a moderator

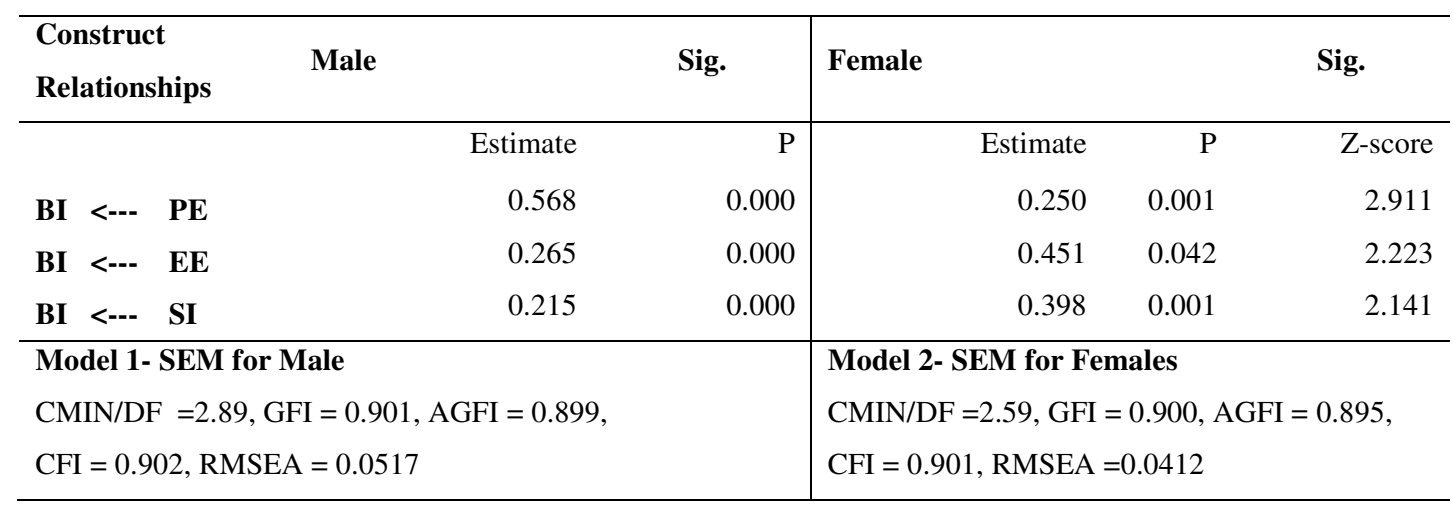

Table 6. Age as a moderator

\begin{tabular}{|c|c|c|c|c|c|}
\hline $\begin{array}{l}\text { Construct } \\
\text { Relationships }\end{array}$ & Young $($ Age $<=35$ years $)$ & Sig. & Old (Age>35 years) & & Sig. \\
\hline & Estimate & $\mathrm{P}$ & Estimate & $\mathrm{P}$ & Z-score \\
\hline BI <-- PE & 0.518 & 0.000 & 0.240 & 0.001 & 2.841 \\
\hline$B I<--E E$ & 0.235 & 0.000 & 0.405 & 0.042 & 2.553 \\
\hline BI <--- SI & 0.265 & 0.000 & 0.498 & 0.001 & 2.641 \\
\hline UB $<---$ FC & 0.225 & 0.000 & 0.448 & 0.001 & 2.391 \\
\hline \multicolumn{3}{|c|}{ Model 1- SEM for Younger Users } & \multicolumn{3}{|c|}{ Model 2- SEM for Older Users } \\
\hline \multicolumn{3}{|c|}{$\mathrm{CMIN} / \mathrm{DF}=2.61, \mathrm{GFI}=0.900, \mathrm{AGFI}=0.889}$, & \multirow{2}{*}{\multicolumn{3}{|c|}{$\begin{array}{l}\mathrm{CMIN} / \mathrm{DF}=2.44, \mathrm{GFI}=0.910, \mathrm{AGFI}=0.898, \\
\mathrm{CFI}=0.912, \mathrm{RMSEA}=0.0312\end{array}$}} \\
\hline $\mathrm{CFI}=0.907, \mathrm{R}$ & $=0.0490$ & & & & \\
\hline
\end{tabular}

Notes: *** Significance at p_0.001; PE- Performance Expectancy, EE- Effort Expectancy, SI- Social Influence, Facilitating Conditions, BI- Behavioral Intention, UB- Use Behavior

found have fitted the data well with all overall fitness indices (CMIN/DF $<3$, GFI, AGFI, CFI $>.90$ \& RMSEA <.07) within acceptable limits. To compare the relationship strengths between constructs of proposed model, the differences in regression weights for respective two categories of a moderator, the Critical Ratio (C.R.) test $(> \pm 1.96, p<.05)$ was used.

\subsubsection{Gender as a moderator}

The impact of PE on BI was stronger for males $(b=0.568)$ than female $(b=0.250)$ and different was significant with $Z$ score $=2.911$ being greater than 1.96 (table5). So our Hla was supported. Similarly, our H2a was also supported with effect of EE on BI being stronger for females $(b=0.451)$ than males $(b$ $=0.265$ ) and difference in impact being found significant with $z=2.223$ (table5) and greater than 1.96. Last hypothesis too was found to be true with effect of SI on BI being stronger for females $(b=0.398)$ than males $(b=0.215)$. The difference in impact was also found significant with $z=2.141$ (greater than standard value 1.96).

So, all our hypothesis H1a, H2a, H3a were supported and confirmed to UTAUT model (Venkatesh et al., 2003).

\subsubsection{Age as Moderator}

In case of Age also, the proposed model 
Confirmed to UTAUT model (Venkatesh et al., 2003). Age was found to be a significant moderator (table6). The effect of PE on BI was stronger for younger users $(b=0.518)$ than for older users $(b=0.240)$ and difference in effect being significant too. The second proposed relationship of EE having more impact on BI for older users than for the younger users too was supported with values of beta for older and younger users being 0.235 and 0.405 respectively. The difference in the impact too was found significant (z score $=2.553$ and is greater than standard value of 1.96). Similarly, the last two hypothesis too were supported with impact of SI on BI ( $b_{\text {older user }}=0.498$ $\left.>b_{\text {younger user }}=0.265\right)$ and $\mathrm{UB}$ on FC $\left(b_{\text {older }}\right.$ user $\left.=0.448>b_{\text {younger user }}=0.225\right)$ being more in case of older users. The differences in impact were found significant with all $\mathrm{z}$ scores being greater than standard value of 1.96 .

\subsubsection{Experience as Moderator}

Experience too was found to be a significant moderator in the proposed model as shown in Table 7. It also confirmed to UTAUT model (Venkatesh et al., 2003). Hypothesis $\mathrm{H} 2 \mathrm{c}, \mathrm{H} 3 \mathrm{c}, \mathrm{H} 4 \mathrm{~b}$ were supported respectively to conclude that effect of EE on BI was stronger for users who have less or no experience $(b=0.535)$ than those who were experienced users $(b=0.365)$, effect of SI on BI was stronger for experienced users $(b=0.595)$ than for inexperienced users (0.475) and effect of FC on UB found to be

Table 7. Experience as a moderator

\begin{tabular}{|c|c|c|c|c|c|}
\hline $\begin{array}{c}\text { Construct } \\
\text { Relationships }\end{array}$ & $\begin{array}{l}\text { Little or no experience } \\
\qquad(<=1 \text { years })\end{array}$ & Sig. & $\begin{array}{c}\text { More Experience } \\
\text { (> } 1 \text { years) }\end{array}$ & & Sig. \\
\hline & Estimate & $\mathrm{P}$ & Estimate & $\mathrm{P}$ & Z-score \\
\hline BI $<--\quad E E$ & 0.535 & 0.000 & 0.365 & 0.042 & 2.013 \\
\hline BI <-- SI & 0.475 & 0.000 & 0.595 & 0.002 & 1.991 \\
\hline UB $<---$ FC & 0.225 & 0.000 & 0.448 & 0.001 & 2.241 \\
\hline $\begin{array}{l}\text { Model 1- SEM f } \\
\mathrm{CMIN} / \mathrm{DF}=2.32 \\
\mathrm{CFI}=0.0905, \mathrm{RN}\end{array}$ & $\begin{array}{l}\text { sers with No experience } \\
\mathrm{I}=0.901, \mathrm{AGFI}=0.879, \\
\mathrm{~A}=0.0517\end{array}$ & & \multicolumn{3}{|c|}{$\begin{array}{l}\text { Model 2- SEM for experienced users } \\
\mathrm{CMIN} / \mathrm{DF}=2.27, \mathrm{GFI}=0.913, \mathrm{AGFI}=0.902, \\
\mathrm{CFI}=0.911, \mathrm{RMSEA}=0.0332\end{array}$} \\
\hline
\end{tabular}

Notes: *** Significance at p_0.001, EE- Effort Expectancy, SI- Social Influence, Facilitating Conditions, BI- Behavioral Intention, UB- Use Behavior

Table 8. Voluntariness of Use as a moderator

\begin{tabular}{|c|c|c|c|c|c|}
\hline $\begin{array}{c}\text { Construct } \\
\text { Relationships }\end{array}$ & Non-Voluntary & Sig. & \multicolumn{2}{|l|}{ Voluntary } & Sig. \\
\hline & Estimate & $\mathrm{P}$ & Estimate & $\mathrm{P}$ & Z-score \\
\hline BI $<---\quad$ SI & 0.675 & 0.000 & 0.395 & 0.002 & 2.961 \\
\hline \multicolumn{2}{|c|}{$\begin{array}{l}\text { Model 1- SEM for Non-voluntary use } \\
\mathrm{CMIN} / \mathrm{DF}=1.91, \mathrm{GFI}=0.910, \mathrm{AGFI}=0.900, \\
\mathrm{CFI}=0.910, \mathrm{RMSEA}=0.0317\end{array}$} & & \multicolumn{3}{|c|}{$\begin{array}{l}\text { Model 2- SEM for Voluntary use } \\
\text { CMIN/DF }=2.47, \text { GFI }=0.900, \mathrm{AGFI}=0.896, \\
\mathrm{CFI}=0.912, \mathrm{RMSEA}=0.0342\end{array}$} \\
\hline
\end{tabular}

Notes: *** Significance at p_0.001; SI- Social Influence, Facilitating Conditions, BI- Behavioral Intention 
Table 9. Perceived risk as a moderator

\begin{tabular}{|c|c|c|c|c|c|}
\hline $\begin{array}{c}\text { Construct } \\
\text { Relationships }\end{array}$ & $\begin{array}{c}\text { Perceived Risk is } \\
\text { Low }\end{array}$ & Sig. & \multicolumn{2}{|l|}{$\begin{array}{c}\text { Perceived Risk is } \\
\text { High }\end{array}$} & Sig. \\
\hline & Estimate & $\mathrm{P}$ & Estimate & $\mathrm{P}$ & Z-score \\
\hline BI <--- PE & 0.768 & 0.000 & 0.350 & 0.002 & 3.841 \\
\hline BI <-- $E E$ & 0.465 & 0.000 & 0.151 & 0.042 & 2.721 \\
\hline BI <--- SI & 0.515 & 0.000 & 0.101 & 0.001 & 3.341 \\
\hline \multicolumn{3}{|c|}{$\begin{array}{l}\text { Model 1- SEM for Low Perceived Risk } \\
\mathrm{CMIN} / \mathrm{DF}=1.89, \mathrm{GFI}=0.911, \mathrm{AGFI}=0.899, \\
\mathrm{CFI}=0.922, \mathrm{RMSEA}=.0557\end{array}$} & \multicolumn{3}{|c|}{$\begin{array}{l}\text { Model 2- SEM for Low Perceived Risk } \\
\text { CMIN/DF }=2.79, \text { GFI }=0.901, \text { AGFI }=0.886, \\
\text { CFI }=0.911, \text { RMSEA }=0.0622\end{array}$} \\
\hline
\end{tabular}

Notes: *** Significance at p_0.001; PE- Performance Expectancy, EE- Effort Expectancy, SI- Social Influence, Facilitating Conditions, BI- Behavioral Intention, UB- Use Behavior

stronger for experienced users $(b=0.448)$ than for inexperienced users $(b=0.225)$. All differences in effects were found significant with all $z$ scores being more than standard $z$ values of 1.96.

\subsubsection{Voluntariness of Use as moderator}

Voluntariness of Use was found to be a significant moderator in the proposed model as shown in Table 8. It also confirmed to UTAUT model (Venkatesh et al., 2003). Hypothesis H3d was supported to conclude effect of SI on BI was stronger under the conditions of mandatory use $(b=0.675)$ than for conditions under voluntary use $(b=0.395)$ and difference in impact too was significant with $\mathrm{Z}$ value 2.961 being greater than 1.96 .

\subsubsection{Perceived Risk as a Moderator}

Perceived risk has been included as one of the moderator in the UTAUT model. The results of moderating role of perceived risk on the relationships between behavioral intention and factors influencing it have been shown in the Table 9.

Perceived risk was found to be a significant moderator in the proposed model as shown in Table 9. Hypothesis H1c, H2d, $\mathrm{H} 3 \mathrm{e}$ were supported respectively to conclude effect of PE on BI was stronger when perceived risk was low $(b=0.768)$ than when perceived risk was high ( $b=0.350)$, effect of EE on BI was stronger when perceived risk was low (0.465) than when perceived risk was high $(b=0.151)$, effect of SI on BI was stronger when perceived risk was low $(b=0.515)$ than when perceived risk was high $(b=0.101)$. The difference in impact too was significant with $\mathrm{Z}$ value 2.961 being greater than 1.96 .

\section{DISCUSSION}

The main purpose to this study was to analyze the factors that affect cloud computing services adoption in India using UTAUT model (Venkatesh et al., 2003). Using the model, it was conceptualized that intention to adopt cloud computing services (BI-Behavioral Intentions) is positively affected by Performance Expectancy (PE), Effort Expectancy (EE) and Social Influence (SI). Further, Facilitating Conditions (FC) has a direct positive effect on use behavior (UB). Also, Intention to adopt cloud services influences the actual use of cloud computing 
services (UB-Use Behavior) positively. The results of the study Table 1 indicate PE as one the major factor $($ Beta $=0.459)$ followed by EE $($ Beta $=0.411)$, SI $($ Beta $=0.398)$. FC $($ Beta $=0.387)$ and BI impacted UB (Beta $=0.567$ ) significantly as expected. Most of the results were on the expected lines and therefore all hypothesis that were conceptualized using UTAUT model are supported.

Further, the study also tested for the moderating role of gender, age, experience and voluntariness of use on the relationship between factors influencing cloud services adoption intentions (PE, EE, SI, FC) and intention to adopt cloud computing services (BI). It was found that effect of PE on BI was stronger for males but effect of EE and SI on BI was stronger for females. Also, effect of $\mathrm{PE}$ on $\mathrm{BI}$ was stronger for younger users but that of $\mathrm{EE}$ and $\mathrm{SI}$ on $\mathrm{BI}$ was stronger for older users. Effect of FC on UB too was stronger for older users. Effect of EE on BI was stronger for users who had less or no experience but that of SI on BI and FC on UB was stronger for experienced users. Further, the effect of SI on BI was stronger under the conditions of mandatory use.

In addition to these, moderating role of perceived risk, too, has been examined. It was found that perceived risks (PR) has a significant negative impact on the proposed relationships. In other words, higher levels of PR are found to have weakened the impact of PE, EE and SI on BI and vice versa shown in Table 9. These results support all the assumed hypothesis.

\section{CONCLUSIONS}

This study utilized the UTAUT model to understand the consumer adoption of cloud computing services in India. The model is said to be a superior model to understand technology acceptance with six constructs viz. PE, EE, SI, FC, BI and UB. The original model has successfully tested the significant direct impact of four constructs namely PE, $\mathrm{EE}$, SI, an FC on BI. Our study too have similar results. PE has emerged out as one the major determinant of BI followed by PE, $\mathrm{EE}$, and SI. The UTAUT model also has four moderators namely gender, age, experience, Voluntariness. However, the present study too has taken these moderators and were found to be significant moderators as proposed in UTAUT model. Also, a new moderating variable, perceived risk, emerged from the discussion in three focus group studies conducted in exploration phase, was included in the study. Therefore, it was posited that PR will have a significant negative impact on the four relationships between PE \& BI, EE \& BI and SI \& BI. All the assumed hypothesis related to moderating nature of PR were supported.

Despite exhaustive efforts, the study has few limitations. One, our area of operation was only Dehradun region and this may limit the external validity of our results. Also, having a sample size of 309 makes it somewhat difficult to generalize the findings. So, a larger sample size spread over several parts of India may make the results more reliable to take policy level decisions. Second, the study uses UTAUT model to test direct impact of factors that influence intention to adopt cloud services. UTAUT, despite having an explanatory power of approximately $70 \%$, has its limitations such as it does not include other important concepts/variables such as Trust, Cost, Hedonic motivations etc. In future, researchers may think about including these construct and lend it more reliability and 
validity. Thirdly, awareness about cloud computing services usefulness is still not much, especially in India. Therefore, a lot of questions may not have been understood in the manner as intended. So a lot of studies are required to be done here to well understand the phenomenon of cloud computing services adoption. Lastly, the proposed model has to be tested in different contexts in terms of constructs, time, \& places. Researchers may include these dimensions to make these studies more robust.

\section{References}

Ajzen, I., \& Fishbein, M. (1980), Understanding Attitudes and Predicting Social Behaviour, Prentice-Hall, Englewood Cliffs, NJ.

Ajzen, I. (1991). The Theory of Planned Behavior. Organizational Behavior and Human Decision Processes, 50 (2), 179-211.

Alharbi, S.T. (2014). Trust and Acceptance of Cloud Computing: A Revised UTAUT Model. 2014 International Conference on Computational Science and Computational Intelligence, 2, 131-134.

Bagozzi, R.P. (2007). The Legacy of the Technology Acceptance Model and a Proposal for a Paradigm Shift. Journal of the Association for Information Systems, 8(4), 244-254.

Bauer, R. A. (1960). Consumer behavior as risk taking. In R. S. Hancock (Ed.), Dynamic marketing for a changing world. Chicago: American Marketing Association, 389-398.

Bettman, J.R. (1973). Perceived Risk and Its Components: A Model and Empirical Test. Journal of Marketing Research, 10(2), 184-190.
Burda, D., \& Teuteberg, F. (2014). The role of trust and risk perceptions in cloud archiving - Results from an empirical study. The Journal of High Technology Management Research, 25(2), 172-187.

Cao, Y., Bi, X., \& Wang, L. (2013). A Study on User Adoption of Cloud Storage Service in China: A Revised Unified theory of Acceptance and Use of Technology Model. 2013 International Conference on Information Science and Cloud Computing Companion, 287-293.

Chang, S. S., Lou, S. J., Cheng, S. R., \& Lin, C., L. (2015). Exploration of usage behavioral model construction for university library electronic resources. The Electronic Library, 33(2), 292-307.

Chonka, A., Xiang, Y., Zhou, W, \& Bonti, A. (2011). Cloud security defense to protect cloud computing against HTTP-DOS and XML-DOS attacks. Journal of Network and Computer Applications, 34(4), 1097-1107.

Davis, F.D., Bagozzi, R.P., \& Warshaw, P.R. (1989). User acceptance of computer technology: a comparison of two theoretical models. Management Science, 35(8), 9821003.

Davis, F.D., Bagozzi, R.P., \& Warshaw, P.R. (1992). Extrinsic and Intrinsic Motivation to Use Computers in the Workplace. Journal of Applied Social Psychology, 22(14), 1111-1132.

Dowling, G.R., \& Staelin, R. (1994). A Model of Perceived Risk and Intended RiskHandling Activity. Journal of Consumer Research, 21(1), 119-134.

Engel, J., Blackwell, R., \& Miniard, P. (1986). Consumer Behavior, CBS College Publishing, New York.

Festinger, L. (1957). A Theory of Cognitive Dissonance. Stanford University Press, Stanford CA.

Fishbein, M., \& Ajzen, I. (1975). Belief, 


\title{
ОДРЕЪИВАЊЕ ФАКТОРА КОЈИ УТИЧУ НА ПРИХВАТАЫЕ “CLOUD” УСЛУГА У ИНДИЈИ
}

\author{
Garima Rastogi, Hemraj Verma, Rama Sushil
}

\section{Извод}

У овом истраживању идентификују се фактори који утичу на прихватање „сloud“ услуга у Индији, користећи „Unified Theory of Acceptance and Use of Technology (UTAUT)“ модел. Испитана је и улога перцепционог ризика као модератора у усвајању „сloud“ сервиса са другим модераторима као што су пол, старост, искуство и волунтарност употребе, како је наведено у „UTAUT“ моделу. Након дескриптивног дизајна истраживања, спроведено је испитивање и структуриран упитник је насумично urađen на узорку од 379 испитаника у Дехрадун региону. Већина веза потврдила је „UTAUT“ модел. Очекивани учинак и очекивани напор појавили су се као два најзначајнија фактора који утичу на усвајање услуга „сloud“. Опажени ризик је, такође, играо значајну улогу у усвајању „сloud“ сервиса од стране модератора. Услуге засноване на „сloud“ сервису релативно су нове за потрошаче у Индији. Предности „cloud“ технологије могу се у потпуности искористити ако их све више и више корисника усвоји. Такође, разне врсте ризика, као што су финансијски губици, губитак података, приватност итд. повезују се са коришћењем „сloud“ сервиса. Према томе, ова студија може имати непосредне импликације за „сloud“ пружаоце услуга.

Кључне речи: усвајање, модератор, утицај, услуга, одређивање фактора

Attitude, Intention and Behavior: An Introduction to Theory and Research. Addison-Wesley, Reading, MA.

Germunden, H. G. (1985).Perceived Risk and Information Search: A systematic MetaAnalysis of Empirical Evidence. International Journal of Research in Marketing. 2, 79-100.

Gray, A. (2013). Conflict of laws and the cloud. Computer Law and Security Review, 29(1), 58-65.

Gupta, P., Seetharaman, A., \& Raj, J. R. (2013). The usage and adoption of cloud computing by small and medium businesses. International Journal of Information Management. 33(5), 861-874.

Hair, J.F., Jr., Anderson, R.E., Tatham, R. L., \& Black, W. C. (2010). Multivariate Data Analysis. 7th Edition. Englewood Cliffs, NJ:
Prentice-Hall International.

Karakas, F., \& Manisaligil, A. (2012). Reorienting self-directed learning for the creative digital era. European Journal of Training and Development. 36(7), 712-731.

Lian, J.W. (2015). Critical factors for cloud based e-invoice service adoption in Taiwan: An empirical study. International Journal of Information Management, 35(1), 98-109.

Marchewka, J.T., Liu, C., \& Kostiwa, K. (2007). An application of the UTAUT model for understanding student perceptions using course management software. Communications of the IIMA, 7(2), 93.

Marston, S., Li, Z., Bandyopadhyay, S., Chang, J., \& Ghalsasi, A. (2011). Cloud computing - the business perspective. Decision Support Systems, 51(1), 176-189. 
Min, Q., Ji, S., \& Qu, G. (2008). Mobile commerce user acceptance study in China: a revised UTAUT model. Tsinghua Science \& Technology, 13(3), 257-264.

Nunnally, J.C. (1978). Psychometric Theory-Vol 2, McGraw-Hill, New York, NY.

Langkau, T. F., Opitz, N., Schmidt, N. H., \& Kolbe, L. M. (2012). Technology Acceptance of Cloud Computing: Empirical Evidence from German IT Departments. 45th Hawaii International Conference on System Sciences(HICSS), Maui, Hawaii USA, 1593-1602.

Park, E., \& Kim, K.J. (2014). An Integrated Adoption Model of Mobile Cloud Services: Exploration of Key Determinants and Extension of Information Management, 34(1), 28-36.

Park, S.C., \& Ryoo, S.Y. (2013). An empirical investigation of end-users' switching toward cloud computing: A two factor theory perspective. Computers in Human Behavior, 29(1), 160-170.

Rogers, E.M. (1995). Diffusion of Innovations, The Free Press, New York, NY.

San-Martín, H., \& Herrero, A. (2012). Influence of the user's psychological factors on the online purchase intention in rural tourism: Integrating innovativeness to the UTAUT framework. Tourism Management, 33(1), 341-350.

Shin, D.H. (2013). User centric cloud service model in public sectors: Policy implications of cloud services. Government Information Quarterly, 30(2), 194-203.

Stein, S., Ware, J., Laboy, J., \& Schaffer, H.E. (2013). Improving K-12 pedagogy via a cloud designed for education. International Journal of Information Management, 33(1), 235-241.

Stieninger, M., \& Nedbal, D. (2014). Diffusion and Acceptance of Cloud Computing in SMEs: Towards a Valence
Model of Relevant Factors. 2014 47th Hawaii International Conference on System Sciences. Waikoloa, HI, USA USA, 33073316.

Taylor, C.W., \& Hunsinger, D.S. (2011). A study of student use of cloud computing applications. Journal of Information Technology Management. 22(3), 36-50.

Taylor, S., \& Todd, P. (1995). Assessing IT Usage: The Role of Prior Experience. MIS Quarterly, 19(4), 561.

Taylor, J.W. (1974). The Role of Risk in Consumer Behavior. Journal of Marketing, 38(2), 54-60.

Udo, G., Bagchi, K., \& Maity, M. (2016). Exploring Factors Affecting Digital Piracy Using the Norm Activation and UTAUT Models: The Role of National Culture. Journal of Business Ethics, 135(3), 517-541.

Venkatesh, V., Morris, M.G., Davis, G.B., \& Davis, F.D. (2003). User acceptance of information technology: toward a unified view. MIS Quarterly, 27(3), 425-478.

Vouk, M.A. (2008). Cloud computingissues, research and implementations. Journal of Computing and Information Technology. 16(4), 235-246.

Wu, P. F. (2009). Opening the black boxes of TAM : Towards a Mixed methods approach. International Conference on Information Systems. Paper 101. http:// aisle.aisnet.org/icis2009/101

Wu, W.W. (2011). Mining significant factors affecting the adoption of SaaS using the rough set approach. Journal of Systems and Software, 84(3), 435-441.

Zaltman, G. \& Wallendorf, M. (1983). Consumer Behavior, Wiley, New York. 